\title{
STUDIES ON THE GENUS ATRIPLEX (CHENOPODIACEAE) IN ITALY. VI. NAMES BY MICHELE TENORE: ATRIPLEX AXILLARIS, A. DIFFUSA, AND A. POLYSPERMA
}

\author{
Duilio IAMONICO ${ }^{1}$, Alexander P. SUKHORUKOV ${ }^{2}$
}

\begin{abstract}
The typification of the names Atriplex axillaris, $A$. polysperma (both names are synonyms of $A$. rosea L.), and $A$. diffusa (synonymized with $A$. tatarica here) is discussed. Specimens from Tenore's collection (NAP) and from De Candolle's collection (G-DC) are respectively designated as the lectotypes of $A$. diffusa and A. axillaris, while one collection from NAP is designated as the neotype for the name A. polysperma.

Key words: Atriplex rosea L., Chenopodiaceae, new synonymy, typification.

\section{Izvleček}

V članku obravnavamo tipifikacijo imen vrst Atriplex axillaris, A. polysperma (obe imeni sta sinonima $A$. rosea L.) in $A$. diffusa (sinonim vrste $A$. tatarica). Kot lektotipe vrst $A$. diffusa in $A$. axillaris smo izbrali primerke iz zbirk, ki sta jih osnovala Tenore (NAP) in De Candolle (G-DC), medtem ko smo en primerek iz zbirke NAP izbrali za neotip imena za vrsto $A$. polysperma.

Ključne besede: Atriplex rosea L., Chenopodiaceae, nova sinonimika, tipifikacija.
\end{abstract}

\section{INTRODUCTION}

Atriplex L. is a genus of about 260 species distributed in arid and semiarid regions of Eurasia, America and Australia (Al-Turki et al. 2000, Sukhorukov \& Danin 2009). The recent phylogenetic study by Kadereit et al. (2010) showed that the majority of Atriplex representatives are found to be monophyletic and revealed that genera previously treated as separate (e.g. Blackiella, Haloxanthium, Obione, Senniella) are to be considered congeneric to Atriplex.

In this paper the identities of the Atriplex taxa described by Tenore (1813: 57) are discussed as part of the treatment of the genus Atriplex in its recent limit for the new edition of the Italian
Flora (editor Prof. S. Pignatti) and within the initiative "Italian Loci Classici Census" (Domina et al. 2012) launched in 2010 under the auspices of the Italian Botanic Society (see e.g. Iamonico et al. 2011, Iamonico 2012a, 2012b, 2013a, 2013b, 2013c, Di Pietro et al. 2012, Iamonico \& Peruzzi 2012, Amadei et al. 2013, Peruzzi \& Carta 2013).

\section{MATERIALS AND METHODS}

The work is based on an extensive analysis of the literature, field investigations and examination of the specimens kept in the Herbaria FI, G-DC, LINN, NAP, RO and W (acronyms according to Thiers 2011).

\footnotetext{
${ }^{1}$ Laboratory of Phytogeography and Applied Geobotany, Department PDTA, University of Rome Sapienza, Via Flaminia 72, 00196-Rome, Italy. d.iamonico@yahoo.it

${ }^{2}$ Department of Higher Plants, Biological Faculty, Moscow State University, Vorobyovy Gory 1-12, Moscow 119234, Russia. suchor@mail.ru
} 


\section{RESULTS AND DISCUSSION}

Atriplex axillaris Ten.

Typification: Tenore' protologue (Tenore 1813: 57) consists of a detailed diagnosis, but without indication of the locus classicus and habitat. Information on the habitat and provenance of this taxon was later published by the same author (Tenore 1835-1838). No specimens of the original material were traced in the Tenore collection at NAP and PAL, nor were any collections were found in the larger Italian Herbaria FI and RO. However, we found one specimen at G-DC (Barcode G00465705) bearing Tenore's annotation "Atriplex axillaris Nob.". The collection matches the diagnosis (Tenore 1813: 57) and is selected here as lectotype of the name Atriplex axillaris (Figure 1).

Taxonomic discussion: On the basis of the Tenore's diagnosis and the lectotype, the name $A$. axillaris is referred to $A$. rosea described by Linnaeus (1763: 1493) the diagnosis of which is "ATRIPLEX caule herbaceo, foliis incanis serratis, fructibus quadrangularibus dentatis". Moreover, the characters given by Tenore (1813) correspond to the concept of $A$. rosea (e.g. Akeroyd 1993: 116, Pignatti 1982: 167, Castroviejo 1990: 508). The name A. axillaris is rarely cited in literature and mostly found as a synonym of $A$. rosea (e.g. Moquin-Tandon 1840: 57, De Candolle 1849: 92, Sukhorukov, 2006: 172). The comparison between types [neotype for $A$. rosea (P-Herb. Haller, designated by McNeill et al. 1893: 553) and lectotype for $A$. axillaris ( $\mathrm{G}$, here designated - see Conclusions)] confirms that these two names refer to the same species. So A. axillaris is to be considered a heterotypic synonym of $A$. rosea, and the latter ones has nomenclatural priority.

\section{Atriplex diffusa Ten.}

Typification: As in the previous case, Tenore's protologue (Tenore 1813: 57) comprises only the morphological description. Later Tenore (1835-1838: 295-296) reported the provenance ("Baja", a locality in Naples province, Campania region, Southern Italy) also providing an illustration ("tavola 249. Figure 2") that matches the diagnosis. However, since this image was not cited in the protologue, it is not possible to treat it as original material. In the Tenore collection at NAP there is one sheet (not numbered) bearing three plants, one of which represents a plant with roots, the others are probably parts of problably two different individuals. One label, in Tenore's handwriting, is included on the sheet and reports the Tenore script
"Atriplex diffusa Nob. [= Nobis] Littorale di Baja": this script matches the locus classicus in Tenore (1835-1838: 295-296). It is possible that the three samples refer to the same gathering, but doubts remain because Tenore could have collected the plants on different dates and mounted them in the same sheet (R. Vallariello in verbis, May 2013). The plant with root matches the diagnosis (Tenore 1813: 57), it is the most complete and is selected here as lectotype of the name $A$. diffusa (Figure 2).

Taxonomic discussion: The majority of authors recognized $A$. diffusa under $A$. laciniata L. at variety or form rank [e.g. Moquin-Tandon 1840: 57 and De Candolle (1849: 9) (A. laciniata $\delta$ diffusa), Arcangeli 1884: 592, Arcangeli 1894: 210, and Fiori (1923: 413) (A. laciniata $\gamma$ diffusa), Fiori \& Paoletti (1896-1898) (A. laciniatum $\delta$ tataricum (L.) c. diffusum)]. Bertoloni (1854: 414) synonymized A. diffusa with A. laciniata. The most recent Italian flora (Pignatti 1982: 165-169) and checklists (Conti et al. 2005, 2007) have not cited this name. Tenore (1835-1838: 296) wrote the "Le sue foglie frastagliate all'infuori dell'apice somigliano a quelle dell'A. laciniata" ("its irregular leaves, excepting the apex, are similar to those of A. laciniata"). As noted by Pignatti (1982), the Linnaean name A. laciniata was incorrectly interpreted by most Italian authors. On the basis of $A$. laciniata descriptions reported in the Italian floras, it appears that the "Atriplex laciniata" concept by the Italian botanists is included in the current $A$. tatarica group (sensu Uotila 2011) and in particular in A. tatarica L. (see e.g. Castroviejo 1990: 508-509, Akeroyd 1993: 116). Although the A. tatarica group is quite difficult from the nomenclatural and taxonomical points of view, including about 20 taxa that will discuss by the authors of the present paper in their comprehensive work which is in preparation. The name $A$. diffusa is clearly associated with $A$. tatarica due to aphyllous inflorescence. Therefore, we consider $A$. diffusa as a new synonym of $A$. tatarica as no earlier citation of $A$. diffusa as a synonym of $A$. tatarica was found.

\section{Atriplex polysperma Ten.}

Typification: Tenore's protologue (Tenore 1813: 57) consists of a diagnosis, but with no indication of the locus classicus. Tenore (1835-1838: 295) later reported the provenance, indicating three localities from Central and Southern Italy: “...a Pozzuoli [Campania region] ... a Viesti nel Gargano [Puglia region] ... Chieti alla Cavallerizza ... [Abruzzo region]". Moreover, he provided an illustra- 
tion ("tavola 249. Figure 1") that cannot be considered original material for the name as it was not cited in the protologue. In the Tenore collection at NAP there are seven sheets (not numbered) of which two include Tenore's handwriting that explicitly refer to the localities indicated in Tenore (1835-1838: 295): the first one includes two plants collected at Chieti city with the labels there are ("Atriplex polysperma Ten. Aug. 1835 Chieti" and "Atriplex polysperma Chieti") and the plants are not probably parts of the same gathering, so the art. 9.17 of the ICN cannot be applied. The other one bears two plants, one from Pozzuoli (the lower), with the label "Atriplex polysperma Pozzuoli"), and one from Vieste (the upper), with the label "Atriplex polysperma Viesti"). The plants from Chieti collected in the year 1835 cannot be eligible as lectotype since the date is later than the protologue publication (1813). The other specimens are not dated, so it is not unequivocally demonstrable that Tenore used these specimens in establishing the diagnosis (see Art. 9.1 Note 1 of the ICN - McNeill et al. 2012). Since no unambiguous original material has been traced, a neotype has to be designated (art 9.7 of the ICN - McNeill et al. 2012). We prefer to select as the neotype of the name $A$. polysperma the exsiccatum from Pozzuoli, since it it the better preserved (Figure 3).

Taxonomic discussion: The name A. polysperma was often cited as a synonym of $A$. rosea (e.g. Moquin-Tandon 1840: 57, Bertoloni 1854: 413, Arcangeli 1884: 591, Arcangeli 1894: 210). Fiori \& Paoletti (1896-1898) reported it as a synonym of $A$. laciniatum L. $\delta$ roseum (L.) a. genuinum that probably refers to the typical form of $A$. rosea. The most recent Italian flora (Pignatti 1982) and checklist (Conti et al., 2005, 2007) have not cited this name. A comparison of the protologues of $A$. polysperma and A. rosea, their neotypes [P-Herb. Haller for $A$. rosea (designated by McNeill et al. 1893: 553) and NAP for A. polysperma (here designated)] and their descriptions in floras, confirm a complete overlap of their characters, and, as a consequence, the synonymy of these names. Crantz (1766: 207) proposed the new combination A. polysperma (L.) Crantz (basionym Chenopodium polyspermum L.), so the name by Tenore is a later homonym and it is illegitimate under the Art. 53.1 of the ICN (McNeill et al. 2012).

Figure 1: Lectotype of the name Atriplex axillaris Ten. (G-DC). Slika 1: Lektotip imena Atriplex axillaris Ten. (G-DC).

\section{CONCLUSIONS}

Analysis of the literature, study of the herbarium specimens and comparison of the protologues allowed the designation of lectotypes for $A$. diffusa and $A$. axillaris, and a neotype for the name $A$. polysperma, and clarifycation of their identities: $A$. diffusa can be considered a synonym of $A$. tatarica (new synonymy), while $A$. axillaris and $A$. polysperma are synonyms of $A$. rosea.

Atriplex rosea L., Sp. Pl., ed. 2, 2: 1493 (1763) Neotype (designated by McNeill et al. 1983: 553): Herb. Haller, "Semen a Zinnio sub nomine Atriplex seminis capsula aculeata ..." (P-HA).

= Atriplex axillaris Ten., Fl. Nap. Prodr. 1: 57 (1813). - Lectotype (designated here by Iamonico and Sukhorukov): Italia. Campania, Baja. "Atriplex axillaris nob." [manus Tenore], "m[isit] Tenore 1814” (G-DC-00465705; Figure 1)

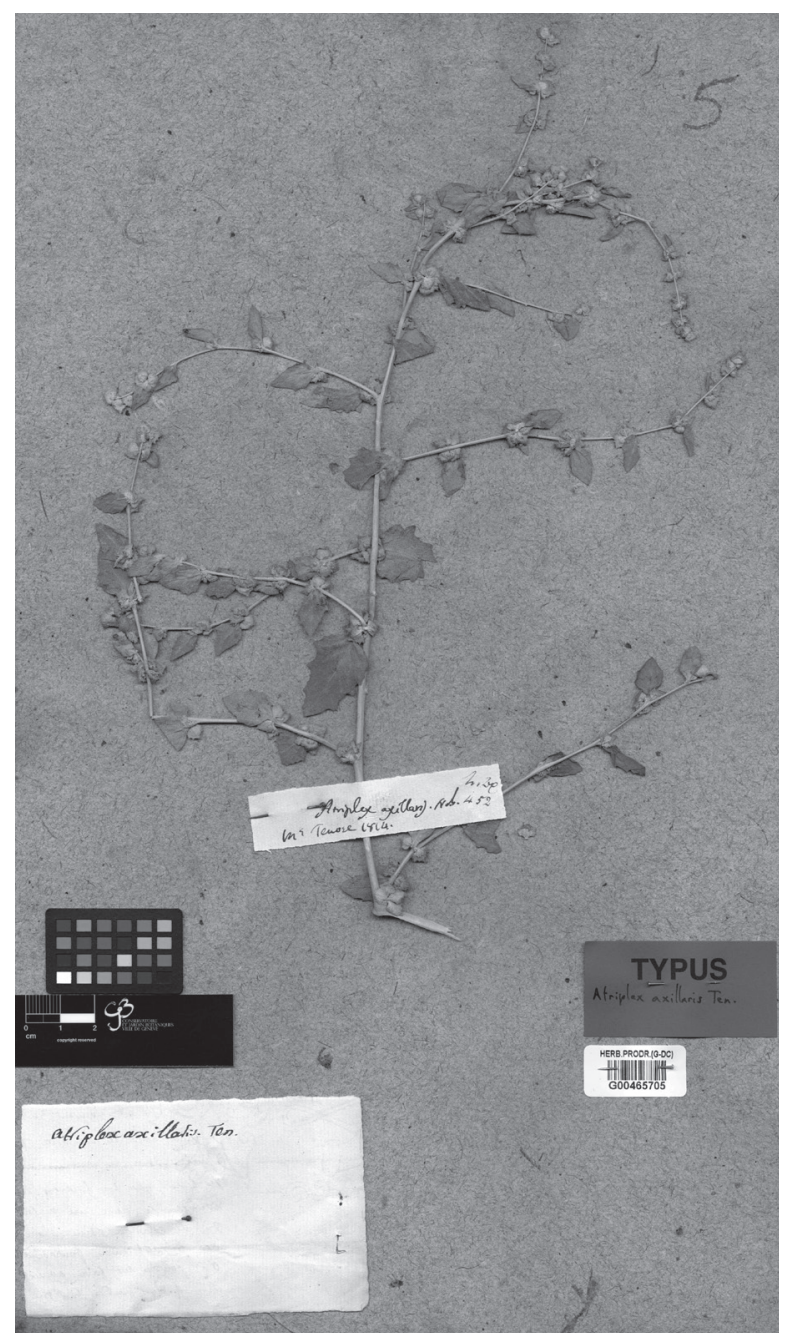




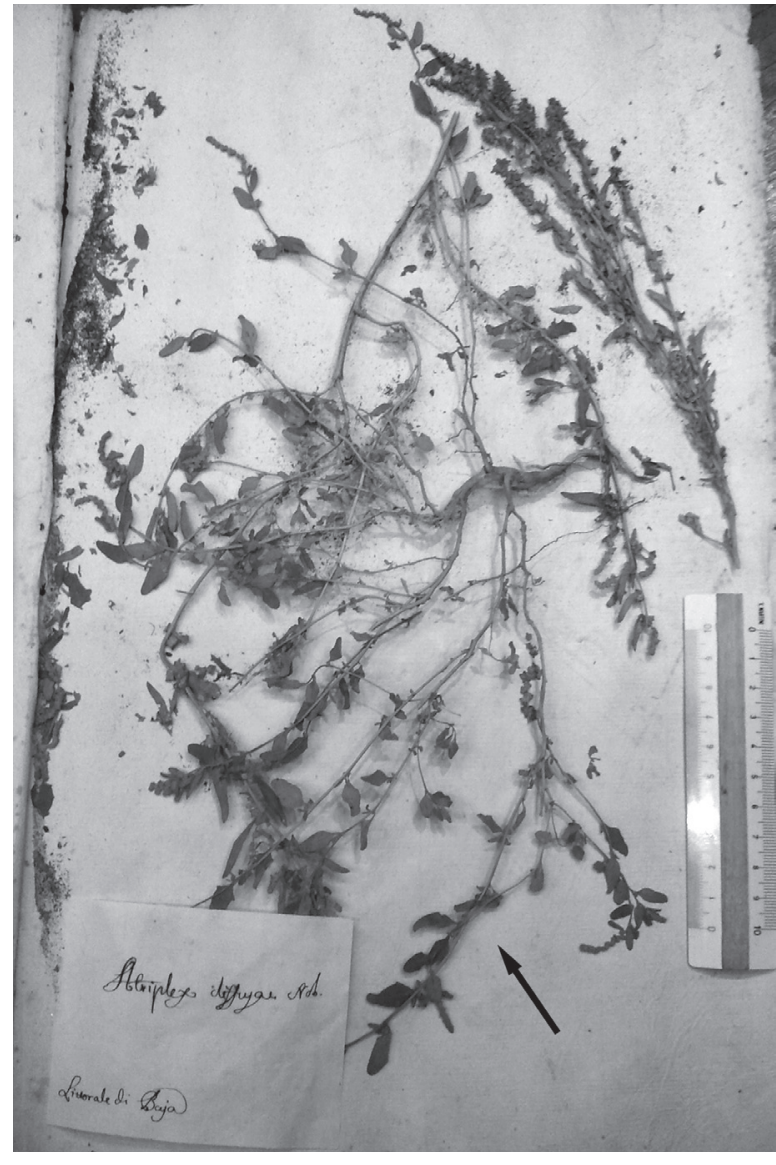

Figure 2: Lectotype (arrow indicates the lectotype) of the name Atriplex diffusa Ten. (NAP).

Figure 2: Lektotip (puščica kaže na lektotip) imena Atriplex diffusa Ten. (NAP).

= Atriplex polysperma Ten., Fl. Nap. Prod. 1: 57 (1813), nom. illeg. non (L.) Crantz (1766: 207) Neotype (designated here by Iamonico and Sukhorukov): Pozzuoli, sine die, M. Tenore s.n. (NAP; Figure 3, lower plant indicated by an arrow).

Atriplex tatarica L., Sp. Pl., 2: 1053 (1753) - Lectotype (designated by Hedge 1997: 75): Herb. Linnaeus, No. 1221.10 (LINN!).

= Atriplex diffusa Ten., Fl. Nap. Prod. 1: 57 (1813), syn. nov. - Lectotype (designated here by Iamonico and Sukhorukov): "Atriplex diffusa nob." [manus Tenore], Littorale di Baja, sine die, Tenore s.n. (NAP; Figure 2).

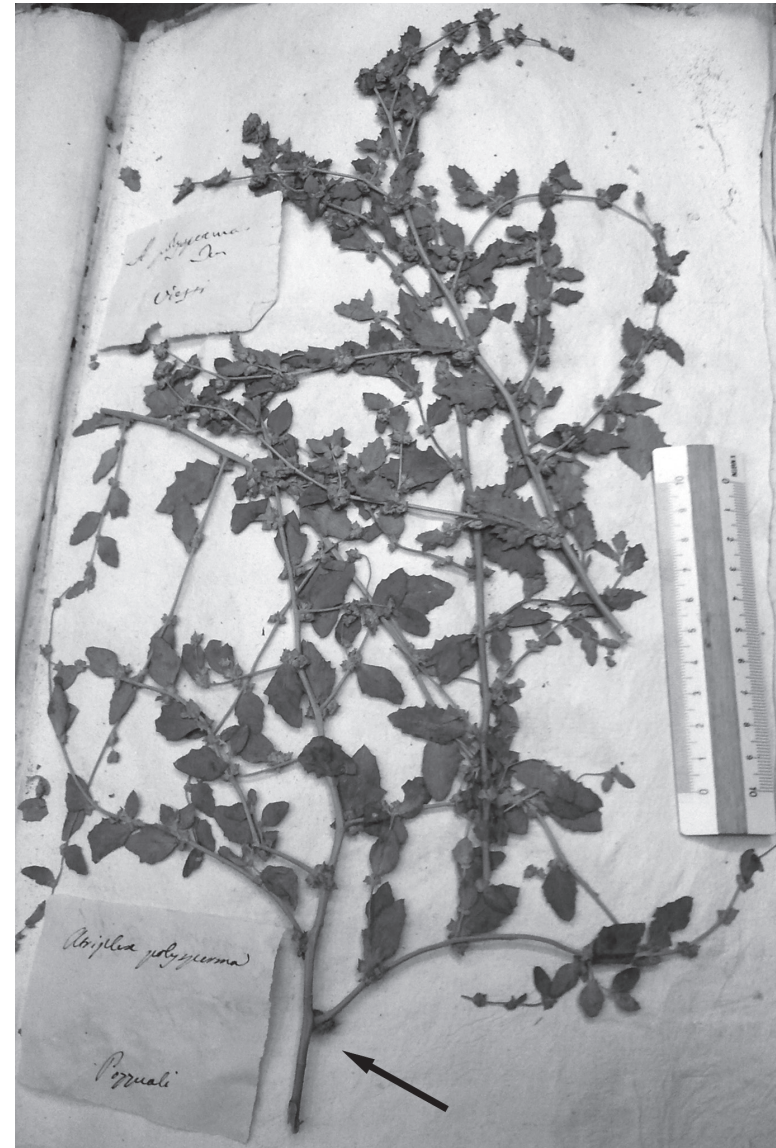

Figure 3: Neotype of the name Atriplex polysperma Ten. (NAP); arrow indicates the neotype.

Slika 3: Neotip imena Atriplex polysperma Ten. (NAP); puščica kaže na neotip.

\section{ACKNOWLEDGEMENTS}

We are grateful to the Directors and Curators of all quoted Herbaria for their support during my visits, loan of specimens/photographs or requests for informations. Special thanks to R. Vallariello (Napoli, Italy), L. Gautier and N. Fumeaux (Genéve, Switzerland) for their permission to reproduce the images of the specimens of Tenore and for the discussion of the parts of the present article. We also thank to A. Sennikov for the constructive comments. The research is partially supported by RFBR-grant11-04-00123 and 14-0400136-a. 


\section{REFERENCES}

Akeroyd, J. R. 1993: Atriplex L. In: Tutin, T. G., Burges, N. A., Chater, A. O., Edmondson, J. R., Heywood, V. H., Moore, D. M., Valentine, D. H., Walters, S. M. \& Webb, D. A. (eds.): Flora Europaea (second edition), 1. Cambridge University Press, Cambridge, pp 115-177.

Al-Turki, T. A., Omer, S. \& Ghafoor, A. 2000: A synopsis of the genus Atriplex L. (Chenopodiaceae) in Saudi Arabia. Feddes Repertorium 111(5-6): 261-293.

Amadei, L., Baldini, R., Maccioni, S. \& Peruzzi, L. 2013: Lectotypification of two Origanum names (Lamiaceae) described by Gaetano Savi. Atti della Società Toscana di Scienze Nataurali, Memorie, serie B 119 (in press).

Arcangeli, G. 1882: Compendio della flora italiana. Ermanno Loescher, Torino, 889 pp.

Arcangeli, G. 1894: Flora italiana ed. 2. Tipografi Vincenzo Bona, Torino, $836 \mathrm{pp}$.

Bertoloni, A. 1854: Flora italica, sistens plantas in Italia et in insulsi circumstandibus sponte nascentes, 10. Ex Typographaeo Haeredum Richardi Masii, Bologna, 640 pp.

Castroviejo, S. 1990: Atriplex L. In: Castroviejo, S., Laínz, M., López Gonzáles, G., Montserrat, P., Muñoz Garmendia, F., Paiva, J. \& Villar, L. (eds.): Flora Iberica, 2. Real Jardin Botanico, Madrid, pp 503-513.

Conti, F., Abbate, G., Alessandrini, A. \& Blasi, C. (eds.) 2005: An annotated checklist of the Italian vascular flora. Palombi \& Partner, Roma, 420 pp.

Conti, Alessandrini, A., Bacchetta, G., Banfi, E., Barberis, G., Bartolucci, F., Bernardo, L., Bonacquisti, S., Bouvet, D., Bovio, M., Brusa, G., Del Guacchio, E., Foggi, B., Frattini, S., Galasso, G., Gallo, L., Gangale, C., Gottschlich, G., Grünanger, P., Gubellini, L., Iiriti, G., Lucarini, D., Marchetti, D., Moraldo, B., Peruzzi, L., Poldini, L., Prosser, F., Raffaelli, M., Santangelo, A., Scassellati, E., Scortegagna, S., Selvi, F., Soldano, A., Tinti, D., Ubaldi, D., Uzunov, D. \& Vidali, M. 2007: Integrazioni alla checklist della flora vascolare italiana. Natura Vicentina 10 (2006): 5-74.

Crantz, H. J. N. 1766: Institutione Rei Herbariae, 1. Ioannis Pauli Kraus, Wien, 697 pp.

De Candolle, A. P. 1849: Prodromus Systematis Naturalis Regni Vegetabilis, 13(2). Sumptibus Victoris Masson, Parisiis, 468 pp.

Di Pietro, R., Viscosi, V., Peruzzi, L. \& Fortini, P.
2012: A review of the application of the name Quercus dalechampii. Taxon 61(6): 1311-1316.

Domina, G., Giusso Del Galdo, G., Gargano, D., Labra, M., Peccenini, S., Peruzzi, L. \& Raimondo, F. M. 2012: The Italian Loci Classici Census. Taxon 61(6): 1351-1353.

Fiori, A. 1923: Nuova Flora Analitica Italiana, 1. Ed. M. Ricci, Firenze.

Fiori, A. \& Paoletti, G. 1898: Flora Analitica Italia, 2. Tipografia del Seminario, Padova, $607 \mathrm{pp}$.

Hedge, I. 1997: Atriplex tatarica L. In: Rechinger, K. H. (ed.), Flora Iranica, 172. Akad. Druckund Verlagsanstalt, Graz, pp. 63-87.

Iamonico, D., Giovi, E., Iberite, M. \& Abbate, G. 2011: Typification of Trifolium latinum Sebast. (Fabaceae) and comparison with related species. Annales Botanici Fennici 48(6): 459-464.

Iamonico, D. 2012a: Amaranthus powellii S. Watson subsp. cacciatoi comb. \& stat. nov. (Amaranthaceae). Nordic Journal of Botany 30(1): 12-16.

Iamonico, D. 2012b: Studies on the genus Atriplex L. (Amaranthaceae) in Italy. II. Lectotypification of Atriplex elongata Guss. (Amaranthraceae). Candollea 67(1): 181-185.

Iamonico, D. 2013a: Taxonomical and chorological study on the Central Mediterranean Basin endemic Arenaria bertolonii Fiori \& Paol. (Caryophyllaceae). Plant Biosystems 147(4): 923-930.

Iamonico D. 2013b: Lectotypification of the Linnaean name Senecio doria L. (Asteraceae). Annales Botanici Fennici 50(1): 71-72.

Iamonico D. 2013c: Studies on the genus Atriplex L. (Amaranthaceae) in Italy. V. Atriplex tornabenei. Phytotaxa 145(1): 54-60.

Iamonico D. \& Peruzzi L. 2012: Lectotypification of the Linnaean name Acanthus spinosus (Acanthaceae). Phytotaxa 62: 11-12.

Kadereit G., Zacharias E., Mavrodiev E., Sukhorukov A. P. 2010: Molecular phylogeny of Atripliceae (Chenopodioideae, Chenopodiaceae): Implications for systematics, biogeography, flower and fruit evolution, and the origin of C4 photosynthesis. American Journal of Botany 97: 1664-1687.

Linnaeus, C. 1763: Species Plantarum ed. 2, 2. Laurentii Salvii, Holmiae, 899 pp.

McNeill, J., Basset, I. J., Crompton, C. W. \& Taschereau, P. M. 1983: Taxonomic and nomenclatural notes on Atriplex L. (Chenopodiaceae). Taxon 32: 549-556.

McNeill, J., Barrie, F. R., Buck, W. R., Demoulin 
V., Greuter W., Hawksworth D. L., Herendeen P. S., Knapp S., Marhold K., Prado J., Proud'Homme van Reine W. F., Smith J. F. \& Wiersema J. H. (eds.) 2012: International Code of Nomenclature for algae, fungi and plants (Melbourne Code). Gantner, Ruggell.

Moquin-Tandon, A. 1840: Chenopodearum Monografica Enumeratio. Apud P.-J. Loss, Bibliopolam, Parisiis, 182 pp.

Peruzzi L. \& Carta A. 2013: A taxonomic revision of Silene nocturna species complex (Caryophyllaceae) in Italy. Phytotaxa 88(3): 38-48.

Pignatti, S. 1982: Flora d'Italia, 1. Edagricole, Bologna, $790 \mathrm{pp}$.

Sukhorukov, A. P. 2006: Zur Systematik und Chorologie der in Russland und benachbarten Staaten (in den Grenzen der ehemaligen UdSSR) vorkommenden Atriplex-Arten (Chenopodiaceae). Annalen des Naturhistorischen Museums in Wien. 108 B: 307-420.
Sukhorukov, A. P. \& Danin, A. 2009: Taxonomic notes on Atriplex sect. Teutliopsis and sect. Atriplex in Israel and Syria. Flora Mediterranea 19: 15-23.

Tenore, M. 1813: Flora Napolitana (Prodromo), 1. Stamperia Reale, Napoli.

Tenore, M. 1835-1838: Flora Napolitana, 5. P. 295. Stamperia e Cartiera del Fibreno, Napoli.

Thiers, B. 2011: Index herbariorum, a global directory of public herbaria and associated staff. New York Botanical Garden's Virtual Herbarium. http://sweetgum.nybg.org/ih/ (last accessed 21 April 2013).

Uotila, P. 2011: Chenopodiaceae (pro parte majore). In: Euro+Med Plantbase - the information resource for Euro-Mediterranean plant diversity. http://ww2.bgbm.org/EuroPlusMed/ (last accessed 15 June 2013). 